\title{
The Second Record of White-necked Petrel Pterodroma externa cervicalis from Japan
}

\author{
Mark Brazil**
}

On July 12 1987, while travelling north from Chichi-jima, Ogasawara Is., on the ship 'Ogasawara Maru', I observed a single White-necked Petrel Pterodroma externa cervicalis. This bird was seen just north of Chichi-jima at 13: 55 (less than two hours out of harbour) and was kept in view for two to three minutes as it moved north past the ship. It was seen first when it came almost along side and was no more than $100 \mathrm{~m}$ away. It was noticeably and conspicuously different from Bonin Peterls Pterodroma hypoleuca which were seen in the same waters. It appeared larger, longer bodied and longer winged than hypoleuca and rather than a bold dark carpal bar on the underwing it had a very white underwing with only the margins black. In addition to its overall contrastingly patterned appearance with grey upper wings, strongly marked dark carpal bar, and black cap, was the completely white hind-collar. The distinctive hind-collar, the most prominent field character, confirmed that this record was of the subspecies cervicalis.

This record constitutes only the second for Pterodroma externa from Japan and the first observed at sea. The first specimen, also in July, was found in Nagoya city, Aichiken after a typhoon, on 29 July 1962 (Kuroda 1962). Harrison (1983) indicates that the population of P.e. cervicalis which breeds on the Kermadec Islands north of New Zealand, appears to move north past Fiji towards Japan from June on wards. This species is perhaps therefore, to be expected more often in the northwest Pacific off Japan, and may hitherto have been overlooked.

The ferry route to Ogasawara from Tokyo extends virtually $1,000 \mathrm{~km}$ out into the Pacific providing an excellent opportunity for pelagic sea-watching--perhaps some of the finest commercialy available pelagic birding in the world (Brazil in prep.). It seems likely that more $P$. externa and other Pterodroma species are to be found in these waters by those willing to invest the time and effort in travelling to the Ogasawara Islands during summer, when the variety of seabird species in the region seems to be greatest (Brazil 1987).

Other seabirds seen during the same seawatch from 12:00-17:00 were 31 Brown Booby Sula leucogaster, 3 Bonin Petrel Pterodroma hypoleuca, 29 Bulwer's Petrel Bulweria bulwerii, 32 Wedge-tailed Shearwater Puffinus pacificus, 1 Audubon's Shearwater Puffinus lherminieri, 6 Matsudaria's Petrel Oceanodroma matsudairae and 1 Borwn Noddy Anous stolidus.

Received 18 September, 1987

* M. A. Brazil: The Hawk Trust, c/o Zoological Society of London, Regents Park, London NW1 4RY, England (U.K.). 


\section{References}

Brazil, M. A. 1987. A Birdwatcher's guide to Japan. Kodansha International/WBST; Tokyo.

Brazil. M. A. (In prep.) Pelagic birding in Japan.

Harrison, P. 1983. Seabirds. Croom Helm; Beckenham.

Kuroda, N. 1962. The first record of the White-necked Gadfly Petrel Pterodroma externa cervicalis from Japan. Misc. Rep. Yamashina’s Inst. Orn. \& Zool. 3(3): 88-90.

\section{オオシロハラミズナギドリ Pterodroma externa cervicalis の日本第 2 記録}

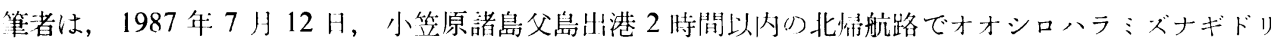
Pterodroma externa cervicalis 1 壮を $100 \mathrm{~m}$ 以内の距離で確涊した。こ机は名古屋への迷鳥記録 (1962 年) 以後日本領海初記録となる。小笠原航路は海鳥観察に好適で他に 7 種を記録した（編者編）。

マーク・ブラジル：The Hawk Trust, c/o Zool. Soc. Lond., Regents Park, London NW1 4RY, England. 